\title{
Time Budget Pressure Sebagai Pemoderasi Pengaruh Due Professional Care dan Pengalaman Audit Pada Kualitas Audit
}

\author{
Putu Dian Indah Savitri ${ }^{1}$ \\ A. A. N. B. Dwirandra ${ }^{2}$ \\ ${ }^{1}$ Fakultas Ekonomi dan Bisnis Universitas Udayana (Unud), Bali, Indonesia \\ email: diansavitri440@yahoo.com/ Telp : 08123884318 \\ ${ }^{2}$ Fakultas Ekonomi dan Bisnis Universitas Udayana (Unud), Bali, Indonesia
}

\begin{abstract}
ABSTRAK
Penelitian ini bertujuan untuk meneliti pengaruh due professional care dan pengalaman audit pada kualitas audit dengan time budget pressure sebagai variabel moderasi. Penelitian ini dilakukan pada Kantor Akuntan Publik di Bali tahun 2016. Jumlah sampel yang diambil 62 auditor yang bersedia berpartisipasi dalam penelitian ini. Sampel dalam penelitian ini ditentukan dengan metode purposive sampling. Teknik analisis data yang digunakan adalah analisis Regresi Linier Berganda dan Moderated Regression Analysis (MRA). Penelitian ini berhasil menunjukkan due professional care dan pengalaman audit berpengaruh positif pada kualitas audit. Penelitian ini juga menunjukkan time budget pressure memperkuat hubungan due professional care pada kualitas audit dengan hasil pengujian moderasi yang menunjukkan pengaruh positif. Hasil pengujian moderasi antara pengalaman audit dengan time budget pressure menunjukkan pengaruh negatif yang artinya time budget pressure memperlemah hubungan antara pengalaman audit pada kualitas audit.
\end{abstract}

Kata kunci: time budget pressure, due professional care, pengalaman audit, kualitas audit.

ABSTRACT

This study aims to examine the effect of due professional care and audit experience on audit quality with time budget pressure as a moderation variable. This study was conducted at Public Accounting Firm in Bali in 2016. The number of samples taken 62 auditors who are willing to participate in this research. The sample in this research is determined by purposive sampling method. Data analysis technique used is analysis of Multiple Linear Regression and Moderated Regression Analysis. This research successfully demonstrated due professional care and audit experience had a positive effect on audit quality. This study also shows the time budget pressure to strengthen the due professional care relationship on audit quality with moderation test results showing a positive effect. The result of moderation testing between audit experience and time budget pressure shows a negative influence which means time budget pressure weakens the relationship between audit experience on audit quality.

Keywords: time budget pressure, due professional care, audit experience, audit quality.

\section{PENDAHULUAN}

Auditing adalah suatu proses pemeriksaan terhadap laporan keuangan perusahaan

klien yang dilakukan oleh seseorang yang independen dan kompeten. Audit dalam

bentuk umum yaitu pengumpulan dan evaluasi bukti mengenai informasi untuk 
menentukan dan melaporkan derajat kesesuaian antara informasi tersebut dengan kriteria yang telah ditetapkan (Arens et al., 2011:4). Sehingga yang perlu diperhatikan oleh para auditor dalam proses pengauditan yaitu kualitas audit dalam menyajikan laporan keuangan.

Agar laporan audit yang dihasilkan dapat berkualitas dalam pengambilan keputusan, auditor harus benar-benar melaksanakan prosedur audit sesuai dengan ketentuan yang telah ditetapkan dalam Standar Profesional Akuntan Publik (SPAP). Para pemakai laporan keuangan selalu melakukan pemeriksaan dan mencari informasi tentang kehandalan laporan keuangan perusahaan. Cara mencari informasi tersebut andal adalah dengan melakukan audit secara independen agar informasi yang digunakan dalam pengambilan keputusan lengkap, akurat, dan tidak bias.

Untuk menunjang profesionalismenya sebagai akuntan publik, maka auditor harus melaksanakan tugas auditnya dengan berpedoman pada standar audit yang ditetapkan oleh Institut Akuntan Publik Indonesia (IAPI), yaitu standar umum, standar pekerjaan lapangan, dan standar pelaporan. Standar umum menekankan pada pentingnya kualitas pribadi yang harus dimiliki auditor baik pelatihan dan kecakapan teknis yang memadai untuk melaksanakan prosedur audit, sedangkan standar pekerjaan lapangan dan pelaporan berkaitan dengan pengumpulan bukti dan aktivitas lain selama pelaksanaan audit yang sebenarnya serta auditor harus menyiapkan laporan mengenai laporan keuangan secara keseluruhan, termasuk pengungkapan informatif. 
Adapun kasus yang terjadi pada tahun 2003 yaitu PT Telkom tentang tidak diakuinya KAP Eddy Pianto oleh United States Securities and Exchange Commission (SEC), dimana SEC selaku badan independen dari pemerintah Amerika yang bertanggung jawab untuk mengawasi pelaksanaan dari peraturanperaturan di bidang perdagangan efek dan mengatur pasar perdagangan pada bursa efek, sehingga memiliki alasan khusus mengapa mereka tidak mengakui keberadaan KAP Eddy Pianto (Alim et al., 2007:2). Kemudian kasus Enron dan Kantor Akuntan Publik (KAP) Arthur Andersen yang sudah melanggar kode etik yang seharusnya menjadi pedoman dalam melaksanakan tugasnya dan bukan untuk dilanggar, karena perbuatan mereka inilah, keduanya menuai kehancuran dimana Enron bangkrut dengan meninggalkan hutang milyaran dolar, sedangkan KAP Arthur Andersen kehilangan keindependensiannya dan kepercayaan dari masyarakat terhadap kinerja KAP tersebut, juga berdampak pada karyawan yang bekerja di KAP Arthur Andersen.

Selain itu, ada juga kasus yang dimuat di media online (http://regional.kompas.com) mengenai seorang akuntan publik bernama Biasa Sitepu diduga terlibat dalam kasus korupsi kredit macet, karena terlibat dalam pembuatan laporan keuangan Raden Motor guna memperoleh pinjaman senilai Rp52 miliar dari BRI Cabang Jambi tahun 2009 lalu. Hal tersebut bisa saja terkait dengan due professional care, akuntabilitas dan time budget pressure yang dimiliki oleh auditor masih diragukan oleh SEC, dimana hal tesebut harus dimiliki oleh auditor. Kode Etik Profesi menjelaskan dalam menjalankan tugasnya, anggota KAP harus selalu mempertahankan sikap mental independen di dalam 
memberikan jasa profesional sebagaimana diatur dalam Standar Profesional Akuntan Publik (SPAP) yang diterbitkan oleh IAPI.

Adanya kasus-kasus seperti itulah yang kemudian mempengaruhi persepsi masyarakat, khususnya para pemakai laporan keuangan yang menyebabkan integritas, objektivitas dan kinerja dari seorang auditor mulai diragukan. Dalam hal ini KAP perlu meningkatkan kualitas audit untuk meningkatkan integritas auditor agar kembali dapat dipercaya pihak yang berkepentingan dengan memperhatikan due professional care dan pengalaman audit auditor. Para pengguna jasa KAP tentunya sangat mengharapkan agar para auditor dapat memberikan opini yang tepat sehingga dapat tercapainya laporan keuangan auditan yang berkualitas karena kualitas audit yang tinggi akan menghasilkan laporan keuangan yang dapat dipercaya sebagai dasar pengambilan keputusan bagi para penggunanya. Kepercayaan yang besar dari para pemakai laporan keuangan auditan dan jasa lainnya yang diberikan, mengharuskan akuntan publik memperhatikan kualitas audit yang dihasilkan.

Kusharyanti (2003) mendefinisikan kualitas audit sebagai probabilitas bahwa auditor akan menemukan dan melaporkan pelanggaran pada sistem akuntansi klien. Sedangkan probabilitas untuk menemukan pelanggaran tergantung pada kemampuan teknis auditor dan probabilitas melaporkan pelanggaran tergantung pada independensi yang dimiliki auditor (Batubara, 2008). Akan tetapi Elfarini (2007) mengatakan bahwa kualitas audit merupakan segala kemungkinan (probability) dimana auditor pada saat mengaudit laporan keuangan klien dapat menemukan pelanggaran yang terjadi dalam sistem akuntansi klien 
dan melaporkannya dalam laporan keuangan auditan, dimana dalam melaksanakan tugas tersebut auditor berpedoman pada standar auditing dan kode etik akuntan publik yang relevan. Kualitas audit yang baik pada prinsipnya dapat dicapai jika auditor menerapkan standar-standar dan prinsip-prinsip audit, bersikap bebas tanpa memihak, patuh kepada hukum serta mentaati kode etik profesi. Standar Profesional Akuntan Publik (SPAP) adalah pedoman yang mengatur standar umum pemeriksaan akuntan publik, mengatur segala hal yang berhubungan dengan penugasan, independensi dalam sikap mental.

Salah satu upaya untuk meningkatkan kualitas audit akuntan publik harus bersikap due professional care. Due professional care lebih diartikan pada kemahiran profesional yang cermat dan seksama. Kemahiran profesional menuntut auditor untuk selalu berpikir kritis terhadap bukti audit yang ditemukannya. Due professional care merupakan hal penting yang harus diterapkan oleh para akuntan publik agar tercapainya kualitas audit yang memadai dalam pelaksanaan pekerjaan profesionalnya (Nirmala, 2013). Auditor dalam kasus kegagalan audit harus menentukan pada level manakah auditor melakukan kelalaian dengan menilai standar of care untuk mengevaluasi apakah pekerjaan audit yang ditunjukkan cukup untuk menghindari kewajiban dan para penuntut hukum harus menentukan apakah auditor menggunakan due professional care dalam melakukan sebuah audit (Kadous, 2000). Singgih dan Bawono (2010:4) memberikan bukti empiris bahwa due professional care merupakan faktor yang paling berpengaruh terhadap kualitas audit, kegagalan audit dalam kasus fraud (kemungkinan adanya kecurangan) transaksi pihak-pihak terkait disebabkan 
karena kurangnya sikap skeptis dan due professional care auditor daripada kekurangan dalam standar auditing.

Selain sikap due professional care, seorang akuntan publik harus memiliki kemampuan dan ketrampilan dalam memeriksa dan mengatasi masalah dalam tugas audit. Ketrampilan tercermin dari pengalaman yang dialami auditor. Semakin berpengalaman auditor maka semakin teliti dalam menemukan kesalahan dalam laporan keuangan yang akan disajikan dan semakin peka untuk menemukan kesalahan laporan yang akan dibuat dalam menghasilkan kualitas audit akurat dan relevan (Prasetyo, 2015). Penelitian yang dilakukan oleh Kusharyanti (2003) menemukan bahwa auditor yang berpengalaman mempunyai pemahaman yang lebih baik atas laporan keuangan. Hal tersebut didukung oleh hasil penelitian yang dilakukan oleh (Setyorini, 2011) disebutkan bahwa auditor yang tidak berpengalaman akan melakukan kesalahan yang lebih besar dibandingkan dengan auditor yang berpengalaman.

Faktor lain yang mempengaruhi kualitas audit adalah time budget pressure (tekanan anggaran waktu). Bekerja dalam kondisi yang tertekan (dalam waktu) membuat auditor cenderung berperilaku disfungsional. Mc Namara dan Liyanarachchi (2008:10) menyatakan time budget pressure mengakibatkan perilaku menyimpang auditor yang dapat memberikan implikasi serius bagi kualitas audit. Tingginya tekanan waktu dalam melakukan audit, membuat auditor semakin meningkatkan efisiensi dalam pengauditan sehingga seringkali pelaksanaan audit yang dilakukan oleh auditor tidak selalu berdasarkan prosedur dan perencanaan yang sesuai dengan ketentuan yang berlaku (Kurnia dan Shopie, 
2014:50). Tekanan waktu yang dialami auditor dalam melaksanakan audit sangat mempengaruhi kualitas audit. Maka dari itu, auditor seharusnya mampu untuk membuat rencana audit yang lengkap beserta anggaran alokasi waktunya, kemudian akan disesuaikan dengan standar auditing dan peraturan yang berlaku, tanpa terkecuali dengan kesulitan untuk menyeimbangkan antara tanggungjawab kualitas yang dihasilkan dan elemen-elemen lainnya yang mempengaruhi. Penelitian tentang time budget pressure dilakukan oleh Coram, et al (2004:5) terhadap 106 senior auditor menjelaskan secara umum bahwa time budget pressure memberikan pengaruh yang paling besar terhadap perilaku penurunan kualitas audit.

Tekanan time budget dapat mempengaruhi kinerja seorang auditor dalam pengambilan keputusan dan pelaksanaan prosedur audit, pengaruh tersebut ada yang berpengaruh positif dan negatif. Pengaruh positif yang ditimbulkan dari adanya tekanan time budget antara lain terpacunya kinerja auditor untuk dapat menyelesaikan pekerjaannya tepat pada waktunya. Sementara pengaruh negatif dari adanya tekanan time budget adalah akan menimbulkan sikap dalam tindakan profesional yang dapat mengurangi kualitas audit. Karena di bawah tekanan time budget terdapat suatu kecenderungan untuk melakukan tindakan seperti mengurangi sampel pemeriksaan, menerima bukti audit yang lemah dan melakukan peningkatan pemeriksaan yang pada akhirnya dapat mengurangi kualitas audit (Arisinta, 2013: 268).

Penelitian yang dilakukan oleh Ayuni (2008) mengenai pengaruh pendidikan, pelatihan dan pengalaman auditor terhadap kualitas audit atas sistem 
informasi berbasis komputer, menunjukkan bahwa pengalaman auditor berdasarkan jumlah penugasan dan lama bekerja berpengaruh negatif atau berlawanan arah dan tidak signifikan terhadap kualitas audit atas sistem informasi berbasis komputer. Penelitian Futri (2014) menunjukkan bahwa independensi, profesionalisme dan pengalaman tidak berpengaruh terhadap kualitas audit. Sedangkan tingkat pendidikan dan etika profesi berpengaruh signifikan terhadap kualitas audit. Selanjutnya penelitian yang dilakukan oleh Wulandari, dkk (2014) tentang pengaruh pengalaman, pengetahuan, audit tenure, dan peer review terhadap kualitas audit. Hasil dari penelitiannya menunjukkan bahwa pengalaman, pengetahuan dan peer review berpengaruh positif terhadap kualitas audit. Hal tersebut didukung oleh hasil penelitian Prasetyo (2015) membuktikan bahwa pengalaman kerja berpengaruh signifikan terhadap kualitas audit. Penelitian Gasperz (2014) mengenai tekanan anggaran waktu sebagai variabel moderasi terhadap hubungan antara faktor individu dan kualitas audit menunjukkan bahwa tekanan anggaran waktu berpengaruh untuk memoderasi hubungan antara akuntabilitas dan kualitas audit, tekanan anggaran waktu berpengaruh untuk memoderasi hubungan antara kesadaran etis dan kualitas audit, namun tekanan anggaran waktu tidak berpengaruh untuk memoderasi hubungan antara independensi auditor dan kualitas audit. Karena perbedaan dari hasil penelitian tersebut, dan penelitian mengenai time budget pressure sebagai pemoderasi untuk kualitas audit masih sedikit ditemukan, peneliti ingin meneliti kembali pengaruh due professional care dan pengalaman audit pada kualitas audit dengan menambah time budget pressure sebagai variabel moderasi yang mungkin akan 
mempengaruhi kuat lemahnya hubungan antara due professional care dan pengalaman audit pada kualitas audit.

Berdasarkan uraian diatas peneliti tertarik melihat interaksi dari time budget pressure terhadap due professional care dan pengalaman audit pada kualitas audit. Oleh karena itu penulis mengambil judul untuk penelitian adalah : “Time Budget Pressure Sebagai Pemoderasi Pengaruh Due Professional Care dan Pengalaman Audit pada Kualitas Audit Kantor Akuntan Publik di Bali”. Due professional care memiliki arti kemahiran professional yang cermat dan seksama. Kecermatan dan keseksamaan dalam penggunaan kemahiran profesional menuntut auditor untuk melaksanakan skeptisme profesional, yaitu suatu sikap auditor yang berpikir kritis terhadap bukti audit dengan selalu mempertanyakan dan melakukan evaluasi terhadap bukti audit tersebut. Auditor yang gagal dalam menggunakan atau menerapkan sikap skeptis maka akan menghasilkan opini audit yang tidak berdaya guna dan tidak memiliki kualitas audit yang baik (Mansur, 2007).

Penggunaan kemahiran profesional dengan cermat dan seksama memungkinkan auditor untuk memperoleh keyakinan memadai bahwa laporan keuangan bebas dari salah saji material, baik yang disebabkan oleh kekeliruan maupun kecurangan. Auditor yang cermat dan seksama akan dapat menghasilkan audit yang berkualitas. Rahman (2009) menguji due professional care terhadap kualitas audit. Hasil penelitian menunjukkan bahwa due professional care berpengaruh signifikan terhadap kualitas audit. Kemahiran profesional dan keyakinan yang memadai atas bukti-bukti yang ditemukan akan sangat membantu auditor dalam menentukan scope dan metodologi yang akan digunakan dalam 
melaksanakan pekerjaan audit. Dengan beberapa penelitian diatas, maka hipotesis yang diajukan sebagai berikut.

$\mathrm{H}_{1}$ : Due professional care berpengaruh positif pada kualitas audit

Pengalaman audit merupakan tingkat penugasan dan pemahaman auditor dari lamanya auditor tersebut bekerja. Menurut Futri (2014) pengalaman juga terkait dengan masa kerja akuntan publik, semakin lama rentan waktu masa kerja akuntan publik juga berpengaruh terhadap setiap keputusan yang diambil. Hasil penelitian yang dilakukan oleh (Choo dan Trotman, 1991) menunjukkan bahwa auditor yang berpengalaman lebih banyak menemukan butir-butir yang tidak umum dibanding auditor yang kurang berpengalaman. Tetapi untuk menemukan butir-butir yang umum, tidak ada bedanya antara auditor berpengalaman dan auditor yang kurang berpengalaman. Futri (2014) menyatakan, bahwa auditor yang memiliki lebih banyak pengalaman dapat menghasilkan berbagai macam harapan dalam menjelaskan temuan auditnya. Berdasarkan uraian di atas dan beberapa hasil penelitian sebelumnya, hipotesis dapat dirumuskan:

$\mathrm{H}_{2}$ : Pengalaman audit berpengaruh positif pada kualitas audit

Seorang auditor selama menjalankan pekerjaan auditnya harus mempertahankan sikap due professional care karena jika auditor tidak mampu mempertahankan sikap kemahiran profesional yang cermat dan seksama dimana menuntut auditor untuk selalu berpikir kritis terhadap bukti audit yang ditemukannya maka hasil audit dari laporan keuangan yang di auditnya tidak dapat dipercaya. Oleh karena itu, due professional care merupakan hal penting 
yang harus diterapkan oleh para akuntan publik agar tercapainya kualitas audit yang memadai dalam pelaksanaan pekerjaan profesional.

Oktaviani (2012), menyatakan bahwa terdapat hubungan positif antara due professional care dengan kualitas audit. Dengan adanya sikap cermat dan seksama dalam mempertanggungjawabkan pekerjaan audit yang dilakukan, maka auditor tersebut dapat bekerja dengan lebih baik sehingga berdampak pada semakin meningkatkan kualitas audit. Rhode (1978), menemukan bahwa time budget pressure merupakan penyebab potensial dari perilaku penurunan kualitas audit. Berdasarkan uraian diatas dan beberapa hasil penelitian sebelumnya, hipotesis dapat dirumuskan :

$\mathrm{H}_{3}$ : Time budget pressure memperlemah pengaruh due professional care pada kualitas audit

Pengalaman dalam praktek audit merupakan salah satu indikator yang menunjukan keahlian atau profesionalisme seseorang akuntan publik, karena apabila seorang akuntan publik tidak memiliki pengalaman akan berpeluang lebih besar dalam melakukan kesalahan dibandingkan dengan akuntan publik yang telah berpengalaman (Gita, 2014). Alderman dan Deitrick (1982), menemukan time budget pressure sebagai faktor utama yang mempengaruhi tingakatan dari penurunan kualitas audit. Berdasarkan uraian di atas dan beberapa hasil penelitian sebelumnya, hipotesis dapat dirumuskan :

$\mathrm{H}_{4}$ : Time budget pressure memperlemah pengaruh pengalaman audit pada kualitas audit 


\section{METODE PENELITIAN}

Penelitian ini diawali dengan menetapkan suatu tujuan dimana penelitian ini memiliki tujuan untuk mendapatkan bukti secara statistik time budget pressure sebagai pemoderasi pengaruh due professional care dan pengalaman audit terhadap kualitas audit. Penelitian ini dilakukan pada kantor akuntan publik di wilayah Bali yang terdaftar dalam direktori yang diterbitkan oleh Ikatan Akuntan Indonesia tahun 2016 yang seluruhnya berlokasi di Bali. Penelitian ini dilakukan pada Kantor Akuntan Publik (KAP) di Bali yang terdaftar dalam Direktori yang diterbitkan oleh Ikatan Akuntan Publik Indonesia (IAPI) tahun 2016. Lokasi tersebut dipilih untuk memudahkan pengumpulan data karena kantor akuntan publik yang terdaftar dalam Direktori akan mudah diketahui nama beserta alamatnya. Kantor akuntan publik yang terdaftar di Direktori telah memperoleh ijin dari Menteri Keuangan Republik Indonesia sebagai wadah dari akuntan publik dalam melaksanakan pekerjaannya. Dalam penelitian ini, yang menjadi objek penelitian adalah due professional care, pengalaman audit, time budget pressure dan kualitas audit. Jadi penelitian ini di tekankan pada ada atau tidaknya pengaruh antara due professional care, pengalaman audit pada kualitas audit dengan time budget pressure sebagai variabel moderasi.

Variabel yang akan digunakan dalam penelitian ini adalah variabel bebas (independent) dalam penelitian ini adalah due professional care dan pengalaman audit. Variabel terikat (dependent) dalam penelitian ini adalah kualitas audit. Variabel moderator dalam penelitian ini adalah time budget pressure. Kualitas audit merupakan kemungkinan seorang auditor akan menemukan dan melaporkan 
pelanggaran yang ditemukan dalam sistem akuntansi kliennya. Tekanan anggaran waktu adalah suatu kondisi dimana auditor mendapatkan tekanan dari tempatnya bekerja untuk dapat menyelesaikan tugasnya sesuai dengan waktu yang telah ditetapkan. Due Professional Care memiliki arti kemahiran profesional yang cermat dan seksama. Pengalaman audit merupakan pengalaman seseorang yang semakin lama menjadi auditor akan membuat auditor memiliki kemampuan untuk memperoleh informasi yang relevan, mendeteksi kesalahan dan mencari penyebab munculnya kesalahan.

Jenis data yang digunakan dalam peneltian ini adalah data kuantitatif dan data kualitatif. Data kuantitatif meliputi data skor jawaban kuisioner yang terkumpul dan jumlah auditor pada Kantor Akuntan Publik di Bali. Data kualitatif pada penelitian ini meliputi daftar nama Kantor Akuntan Publik di Bali yang tergabung dalam Institut Akuntan Publik Indonesia. Penelitian ini juga menggunakan dua jenis sumber data yaitu data primer dan data sekunder. Data primer pada penelitian yaitu berupa hasil kuesioner atau jawaban dari responden. Data sekunder dalam penelitian ini adalah gambaran umum dan struktur organisasi serta jumlah pegawai pada Kantor Akuntan Publik di Bali.

Populasi penelitian ini adalah seluruh auditor yang bekerja di Kantor Akuntan Publik di Bali sebanyak 82 orang yang terdaftar dalam Directory IAPI tahun 2016. Metode pengambilan sampel yang dipilih adalah non probability sampling dengan teknik purposive sampling. Metode nonprobability sampling merupakan salah satu teknik penentuan sampel yang tidak memberikan kesempatan atau peluang yang sama dari populasi yang ada untuk dijadikan 
sampel (Sugiyono, 2014:120-121). Teknik purposive sampling yaitu teknik penentuan sampel dengan pertimbangan atau kriteria tertentu yang diinginkan oleh peneliti (Sugiyono, 2014:122). Hal ini dilakukan untuk mendapatkan sampel yang relevan terhadap penelitian. Metode pengumpulan data yang digunakan dalam penelitian ini adalah dengan menggunakan kuesioner. Kuesioner yang disebarkan berupa daftar pertanyaan dan pernyataan tertulis kepada responden mengenai due professional care, pengalaman audit dan time budget pressure.

Ridwan (2007) menyatakan bahwa data ordinal (skor kuesioner) harus terlebih dahulu ditransformasi menjadi data interval dengan Method Successive of Internal (MSI) sebelum dilakukan analisis regresi. Nilai pernyataan skala interval inilah yang dapat digunakan dalam perhitungan analisis regresi. Analisis statistik deskriptif digunakan untuk memberikan informasi mengenai karakteristik variabel penelitian. Statistik deskriptif menjelaskan skala jawaban responden pada setiap variabel independen yang diukur dari nilai minimum, nilai maksimum, nilai tengah (mean) dan standar deviasi.

Sebelum dilakukannya uji statistik deskriptif terlebih dahulu dilakukan pengujian instrument penelitian dan uji asumsi klasik. Pengujian instrument penelitian dilakukan dengan melakukan uji validitas dan uji reliabilitas. Pengujian validitas dilakukan dengan menghitung korelasi antara skor masing-masing butir pertanyaan dengan total skor, sehingga didapat nilai pearson correlation. Pengujian ini dilakukan untuk menguji apakah data yang dikumpulkan melalui instrumen penelitian menunjukkan konsistensi internal yang memadai. 
Sedangakan uji asumsi klasik dilakukan dengan melakukan uji normalitas, uji multikolineaitas dan uji heteroskedastisitas.

Perhitungan analisis yang digunakan adalah analisis regresi berganda dengan menggunakan bantuan komputer program SPSS. Regresi Linear untuk menghitung besarnya pengaruh variabel $\mathrm{X}$ dan $\mathrm{Y}$, yang diukur dengan menggunakan koefisien regresi, metode ini menghubungkan variabel dependen dengan variabel independen. Untuk membuktikan kebenaran adanya pengaruh variabel independen dan dependen digunakan analisis regresi dimana variabel bebas (X1) Due Professional Care, (X2) Pengalaman Audit dan (Y) adalah Kualitas Audit.

Selain itu digunakan juga Uji Moderated Regression Analysis (MRA). Uji interaksi atau disebut dengan MRA merupakan aplikasi khusus regresi linier berganda, dimana dalam persamaan regresinya mengandung unsur interaksi. Pengujian interaksi inilah yang digunakan menguji hubungan antara Due Professonal Care dengan kualitas audit dimana Time Budget Pressure digunakan sebagai variabel pemoderasi dan untuk menguji hubungan antara pengalaman audit dengan kualitas audit dimana Time Budget Pressure digunakan sebagai variabel pemoderasi. Adapun model rumus yang digunakan adalah sebagai berikut.

Model 1

$\mathrm{Y}=\alpha+\beta_{1} \mathrm{X}_{1}+\beta_{2} \mathrm{X}_{2}+\mathrm{e}$

Keterangan:

Y $\quad=$ Kualitas Audit

$\alpha \quad=$ Konstanta 


$$
\begin{array}{ll}
\beta_{1}, \beta_{2}, & =\text { Koefisien regresi } \\
\mathrm{X}_{1} & =\text { Due Professional Care } \\
\mathrm{X}_{2} & =\text { Pengalaman Audit } \\
\mathrm{e} & =\text { Error }
\end{array}
$$

\section{Model 2}

$Y=\alpha+\beta_{1} X_{1}+\beta_{2} X_{2}+\beta_{3} X_{3}+\beta_{4} X_{1} X_{3}+\beta_{5} X_{2} X_{3}+e$

Keterangan:

$$
\begin{array}{lll}
\mathrm{Y} & =\text { Kualitas audit } \\
\alpha & =\text { Konstanta } \\
\beta_{1}, \beta_{2}, \beta_{3}, \beta_{4}, \beta_{5}= & \text { Koefisien regresi } \\
\mathrm{X}_{1} & =\text { Due Professional Care } \\
\mathrm{X}_{2} & =\text { Pengalaman audit } \\
\mathrm{X}_{3} & =\text { Time Budget Pressure } \\
\mathrm{X}_{1} \mathrm{X}_{3} & =\text { Interaksi antara Due Professional Care dengan Time } \\
& \text { Budget Pressure } \\
\mathrm{X}_{2} \mathrm{X}_{3} & & \text { Interaksi antara Pengalaman audit dengan Time Budget } \\
\mathrm{e} & & \text { Pressure } \\
& = & \text { Error }
\end{array}
$$

Koefisien Determinasi $\left(\mathrm{R}^{2}\right)$ pada intinya mengukur seberapa jauh kemampuan model dalam menerangkan variasi variabel dependen (Ghozali, 2011). Uji Statistik F digunakan untuk menguji kelayakan atau validitas dari suatu model regresi berganda dan digunakan untuk mengetahui ada tidaknya pengaruh secara bersama-sama (simultan).

\section{HASIL DAN PEMBAHASAN}

Statistik deskriptif memberikan informasi mengenai karakteristik variabelvariabel penelitian yang terdiri atas jumlah pengamatan nilai minimum, nilai maksimum, nilai mean, dan standar deviasi. Tabel 1 memerlihatkan hasil statistik deskriptif sebagai berikut. 
Tabel 1.

Hasil Uji Statistik Deskriptif

\begin{tabular}{lccccc}
\hline \multicolumn{1}{c}{ Variabel } & N & Min. & Max. & Mean & Std. Deviasi \\
\hline Due Professional Care $\left(\mathrm{X}_{1}\right)$ & 60 & 7,92 & 30,27 & 23,0853 & 6,46199 \\
Pengalaman Audit $\left(\mathrm{X}_{2}\right)$ & 60 & 8,80 & 33,14 & 25,3715 & 7,38863 \\
Time Budget Pressure $\left(\mathrm{X}_{3}\right)$ & 60 & 8,79 & 33,89 & 25,3840 & 7,41794 \\
Kualitas Audit $(\mathrm{Y})$ & 60 & 6,00 & 24,71 & 18,9315 & 5,62568 \\
\hline
\end{tabular}

Sumber: Data diolah, 2016

Berdasarkan Tabel 1 diperoleh nilai terendah (minimum) dari jumlah skor jawaban responden untuk variabel due professional care $\left(\mathrm{X}_{1}\right)$ sebesar 7,92 dan nilai tertinggi (maximum) sebesar 30,27. Nilai tengah (mean) dari jumlah skor jawaban responden untuk variabel due professional care sebesar 23,0853, berarti jika jumlah skor jawaban responden lebih besar dari 23,0853 maka termasuk pada responden yang memiliki due professional care tinggi, dan sebaliknya. Nilai deviasi standar dari variabel due professional care adalah sebesar 6,46199 hal ini menunjukkan bahwa sebaran data condong ke kanan tetapi masih dalam batas normal.

Berdasarkan Tabel 1 diperoleh nilai terendah dari jumlah skor jawaban responden untuk variabel pengalaman audit sebesar 8,80 dan nilai tertinggi sebesar 33,14. Nilai tengah (mean) dari jumlah skor jawaban responden untuk variabel pengalaman audit adalah sebesar 25,3715, hal ini berarti jika jumlah skor jawaban responden lebih besar dari 25,3715 maka termasuk pada responden yang memiliki pengalaman audit tinggi, dan sebaliknya. Nilai deviasi standar dari variabel pengalaman audit adalah sebesar 7,38863 hal ini menunjukkan bahwa sebaran data condong ke kanan tetapi masih dalam batas normal.

Berdasarkan Tabel 1 diperoleh nilai terendah dari jumlah skor jawaban responden untuk variabel time budget pressure sebesar 8,79 dan nilai tertinggi 
sebesar 33,89. Nilai tengah (mean) dari jumlah skor jawaban responden untuk variabel time budget pressure sebesar 25,3840, ini berarti jika jumlah skor jawaban responden lebih besar dari 25,3840 maka termasuk pada responden yang memiliki time budget pressure tinggi dan sebaliknya. Nilai deviasi standar dari variabel time budget pressure adalah sebesar 7,66532 hal ini menunjukkan bahwa sebaran data condong ke kanan tetapi masih dalam batas normal.

Berdasarkan Tabel 1 diperoleh nilai terendah dari jumlah skor jawaban responden untuk variabel kualitas audit sebesar 6,00 dan nilai tertinggi sebesar 24,71. Nilai tengah (mean) dari jumlah skor jawaban responden untuk variabel kualitas audit sebesar 18,9315, hal ini berarti jika jumlah skor jawaban responden lebih besar dari 18,9315 maka termasuk pada responden yang memiliki kualitas audit tinggi dan sebaliknya. Nilai deviasi standar dari variabel kualitas audit adalah sebesar 5,62568 hal ini menunjukkan bahwa sebaran data condong ke kanan tetapi masih dalam batas normal.

Hasil uji validitas menunjukkan seluruh indikator pernyataan dalam variabel due professional care, pengalaman audit, time budget pressure dan kualitas audit memiliki pearson correlation yang lebih besar dari 0,3 sehingga seluruh indikator tersebut telah memenuhi syarat validitas data. Nilai cronbach alpha untuk variabel due professional care sebesar 0,971. Nilai cronbach alpha untuk variabel pengalaman audit sebesar 0,976. Nilai cronbach alpha untuk variabel time budget pressure sebesar 0,972. Nilai cronbach alpha untuk variabel kualitas audit sebesar 0,966 . Hal ini berarti bahwa nilai cronbach alpha masing- 
masing variabel lebih besar dari 0,6, maka instrumen yang digunakan dalam penelitian ini dinyatakan reliabel.

Nilai Asymp.Sig (2-tailed) diatas 0,05 yang berarti seluruh data berdistribusi normal. Nilai tolerance variabel bebas tidak ada yang kurang dari 0,10 dan nilai variance inflation factor (VIF) tidak ada yang lebih dari 10, berarti tidak ada multikolinearitas variabel bebas dalam model regresi. Nilai signifikansi masing-masing variabel di atas $\alpha=0,05$. Jadi, dapat disimpulkan bahwa model regresi tidak mengandung adanya heteroskedastisitas.

Tabel 2.

Hasil Analisis Regresi Linear Berganda

\begin{tabular}{|c|c|c|c|c|c|c|}
\hline \multirow{2}{*}{\multicolumn{2}{|c|}{ Variabel }} & \multicolumn{2}{|c|}{$\begin{array}{l}\text { Unstandardized } \\
\text { Coefficients } \\
\end{array}$} & $\begin{array}{c}\text { Standardized } \\
\text { Coefficients }\end{array}$ & \multirow[t]{2}{*}{ Sig. } & \multirow[t]{2}{*}{$\begin{array}{c}\text { Hasil } \\
\text { Hipotesis }\end{array}$} \\
\hline & & B & Std. Error & Beta & & \\
\hline \multirow[t]{3}{*}{1} & (Constant) & $-0,729$ & 1,561 & & 0,642 & \\
\hline & $\begin{array}{l}\text { Due Professional Care } \\
\text { (X1) }\end{array}$ & 0,420 & 0,067 & 0,483 & 0,000 & Diterima \\
\hline & Pengalaman Audit (X2) & 0,393 & 0,059 & 0,516 & 0,000 & Diterima \\
\hline & 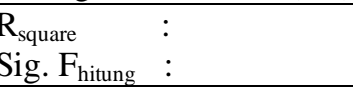 & $\begin{array}{l}0,747 \\
000\end{array}$ & & & & \\
\hline
\end{tabular}

Berdasarkan Tabel 2 dapat dibuat suatu model persamaan regresi linear berganda yaitu sebagai berikut.

$$
Y=-0,729+0,420 X_{1}+0,393 X_{2}+e
$$

Untuk mengetahui apakah variabel time budget pressure mampu memoderasi pengaruh variabel due professional care dan pengalaman audit terhadap kualitas audit maka digunakan model pengujian interaksi (Moderated Regression Analysis-MRA). Model ini bertujuan untuk mengetahui apakah variabel moderasi mampu memengaruhi hubungan antara variabel bebas dan variabel terikat, dimana dalam persamaan regresinya mengandung unsur interaksi 
(perkalian dua atau lebih variabel bebas). Adapun hasil uji interaksi dengan menggunakan program SPSS dapat dilihat pada Tabel 3.

Tabel 3.

Hasil Uji Hipotesis Interaksi (MRA)

\begin{tabular}{|c|c|c|c|c|c|}
\hline \multirow[t]{2}{*}{ Model } & \multicolumn{2}{|c|}{$\begin{array}{c}\text { Unstandardized } \\
\text { Coefficients }\end{array}$} & \multirow{2}{*}{$\begin{array}{c}\text { Standardized } \\
\text { Coefficients } \\
\text { Beta } \\
\end{array}$} & \multirow[t]{2}{*}{ Sig. } & \multirow{2}{*}{$\begin{array}{c}\text { Hasil } \\
\text { Hipotesi } \\
\text { s }\end{array}$} \\
\hline & B & Std. Error & & & \\
\hline (Constant) & $-1,264$ & 1,799 & & 0,485 & \\
\hline $\begin{array}{l}\text { Due Professional } \\
\text { Care (X1) }\end{array}$ & $-0,168$ & 0,123 & $-0,193$ & 0,179 & \\
\hline $\begin{array}{l}\text { Pengalaman Audit } \\
\text { (X2) }\end{array}$ & 0,727 & 0,122 & 0,955 & 0,000 & \\
\hline $\begin{array}{l}\text { Time Budget } \\
\text { Pressure (X3) }\end{array}$ & 0,196 & 0,137 & 0,258 & 0,158 & \\
\hline $\begin{array}{l}\text { Due Professional } \\
\text { Care. Time Budget } \\
\text { Pressure (X1_X3) }\end{array}$ & 0,026 & 0,007 & 1,249 & 0,001 & Ditolak \\
\hline $\begin{array}{l}\text { Pengalaman Audit. } \\
\text { Time Budget } \\
\text { Pressure (X2_X3) }\end{array}$ & $-0,023$ & 0,006 & $-1,200$ & 0,000 & Diterima \\
\hline Adjusted $R_{\text {square }}:$ & 0,833 & & & & \\
\hline Sig. F & 0,000 & & & & \\
\hline
\end{tabular}

Berdasarkan Tabel 3 dapat dibuat suatu model persamaan regresi moderasi yaitu sebagai berikut.

$$
\begin{aligned}
Y & =\alpha+\beta_{1} X_{1}+\beta_{2} X_{2}+\beta_{3} X_{3}+\beta_{4} X_{1} X_{3}+\beta_{5} X_{2} X_{3}+e \ldots \ldots \ldots \ldots \ldots \ldots(3) \\
& =-1,264-0,168 X_{1}+0,727 X_{2}+0,196 X_{3}+0,026 X_{1} X_{3}-0,023 X_{2} X_{3}+e
\end{aligned}
$$

Keterangan :

$$
\begin{aligned}
& \mathrm{Y}=\text { Kualitas Audit } \\
& \mathrm{X}_{1}=\text { Due Professional Care } \\
& \mathrm{X}_{2}=\text { Pengalaman Audit } \\
& \mathrm{X}_{3}=\text { Time Budget Pressure } \\
& \mathrm{X}_{1} \mathrm{X}_{3}=\text { Due Professional Care dengan Time Budget Pressure } \\
& \mathrm{X}_{2} \mathrm{X}_{3}=\text { Pengalaman Audit dengan Time Budget Pressure }
\end{aligned}
$$

Hasil penelitian menunjukkan bahwa nilai $\beta_{1}=0,420$ dengan tingkat signifikansi sebesar 0,000 yang mana nilai signifikansi lebih kecil dari taraf nyata 
dalam penelitian ini, yaitu 0,05 . Artinya bahwa variabel due professional care berpengaruh positif terhadap kualitas audit, maka hipotesis pertama $\left(\mathrm{H}_{1}\right)$ dapat diterima. Kondisi ini menggambarkan bahwa semakin tinggi due professional care, maka kualitas audit yang diberikan akan semakin meningkat. Auditor yang memiliki due professional care akan yakin dengan kemampuan dirinya untuk menyelesaikan pekerjaan-pekerjaannya serta bertanggungjawab pada profesinya akan menimbulkan rasa kepuasan kerja sehingga kualitas yang dihasilkan juga akan meningkat.

Hasil penelitian menunjukkan bahwa nilai $\beta_{2}=0,393$ dengan tingkat signifikansi sebesar 0,000 yang lebih kecil dari taraf nyata dalam penelitian ini. Artinya variabel pengalaman audit berpengaruh positif pada kualitas audit, maka hipotesis kedua $\left(\mathrm{H}_{2}\right)$ dapat diterima. Kondisi ini menggambarkan bahwa terdapat hubungan searah antara pengalaman dengan pelaksanaan kualitas audit, yang berarti semakin banyak pengalaman auditor akan semakin baik kualitas audit yang dihasilkan. Auditor yang berpengalaman cenderung lebih ahli dan memiliki pemahaman yang lebih baik dalam pemeriksaan laporan keuangan. Begitu pentingnya pengalaman ini pemerintah menyaratkan pengalaman auditor harus setidaknya tiga tahun sebagai akuntan dengan reputasi baik untuk mendapatkan izin praktik dalam profesi akuntan publik. Hasil penelitian ini sesuai dengan penelitian yang dilakukan oleh Nur Aini (2009) serta Indah (2010) yang menyatakan bahwa semakin banyak pengalaman audit yang dimiliki oleh auditor maka akan membuat kualitas audit semakin meningkat dan penelitian yang 
dilakukan Saripudin, dkk (2012) yang menunjukkan terdapat pengaruh positif signifikan pengalaman audit auditor terhadap kualitas audit.

Hasil uji statistik interaksi variabel time budget pressure dan due professional care pada kualitas audit diperoleh $p$-value sebesar 0,001 lebih kecil dari $\alpha=0,05$. Hal ini menunjukkan time budget pressure memoderasi hubungan due professional care pada kualitas audit. Hasil ini menolak hipotesis $\mathrm{H}_{3}$. Nilai koefisien regresi sebesar 0,026 menunjukkan time budget pressure sifatnya memperkuat hubungan antara due professional care pada kualitas audit. Dengan semakin tinggi tingkat due professional care akan membuat rasa tanggung jawab terhadap profesinya semakin tinggi pula. Jadi dengan adanya tekanan anggaran waktu ini akan lebih mendorong auditor memiliki rasa tanggung jawab yang lebih besar terhadap profesinya sehingga auditor akan berusaha tepat waktu dalam menyelesaikan auditnya agar mencapai kinerja yang lebih optimal.

Time budget pressure berpengaruh positif pada kualitas audit. Hasil penelitian ini mengindikasikan bahwa adanya pengelolaan anggaran waktu dengan secara cermat, efisien, dan profesional akan cenderung memiliki kualitas audit yang lebih baik. Hal ini dikarenakan dengan adanya tekanan anggaran waktu auditor dapat mengelola laporan audit dengan secara cermat, efisien, dan profesional sehingga dapat berkontribusi positif pada kualitas audit yang dihasilkan. Apabila auditor memiliki sikap yang cermat dan seksama, maka auditor tersebut akan melaksanakan seluruh tanggung jawab yang melekat pada profesinya, sehingga dapat menghasilkan kinerja yang lebih optimal. Hasil penelitian ini mendukung penelitian milik Gundry dan Liyanarachchi yang 
mengatakan bahwa time budget pressure tidak berpengaruh signifikan terhadap penurunan kualitas audit. Namun, hasil penelitian ini tidak konsisten dengan penelitian yang dilakukan Hutabarat (2012) yang menyatakan bahwa time budget pressure berpengaruh negatif signifikan terhadap kualitas audit.

Hasil uji moderasi time budget pressure dan pengalaman audit pada kualitas audit diperoleh $p$-value sebesar 0,000 lebih kecil dari $\alpha=0,05$. Hal ini menunjukkan bahwa time budget pressure memoderasi hubungan pengalaman audit pada kualitas audit. Hasil ini menerima hipotesis $\mathrm{H}_{4}$. Nilai koefisien regresi time budget pressure sebesar -0,023 menunjukkan time budget pressure sebagai variabel pemoderasi sifatnya memperlemah hubungan antara pengalaman audit pada kualitas audit. Artinya bahwa pengalaman adalah tingkat penugasan dan pemahaman auditor dari lamanya auditor tersebut bekerja, semakin lama rentan waktu masa kerja akuntan publik juga berpengaruh terhadap setiap keputusan yang diambil. Hasil penelitian ini mendukung penelitian milik Alderman dan Deitrick (1982) yang menyatakan bahwa time budget pressure sebagai faktor utama yang mempengaruhi tingkatan dari penurunan kualitas audit. Hasil penelitian ini sejalan jika dikaitkan dengan pengaruh secara parsial berpengaruh negatif secara signifikan terhadap kualitas audit yang ditunjukkan oleh penelitian Risma Rizqia (2015) yang mendapatkan hasil bahwa pengalaman audit dan time budget pressure berpengaruh pada kualitas audit.

\section{SIMPULAN}

Berdasarkan hasil penelitian yang diperoleh melalui pengujian statistik serta pembahasan seperti yang telah diuraikan pada bab-bab sebelumnya, maka dapat 
disimpulkan bahwa Due professional care berpengaruh positif terhadap kualitas audit pada Kantor Akuntan Publik Provinsi Bali. Pengalaman audit berpengaruh positif terhadap kualitas audit pada Kantor Akuntan Publik Provinsi Bali. Time budget pressure memoderasi (memperkuat) hubungan antara due professional care terhadap kualitas audit pada Kantor Akuntan Publik Provinsi Bali. Time budget pressure memoderasi (memperlemah) hubungan antara pengalaman audit terhadap kualitas audit pada Kantor Akuntan Publik Provinsi Bali.

Berdasarkan pembahasan hasil penelitian dan simpulan di atas maka saran yang dapat diberikan adalah sebagai berikut. Hasil penelitian ini diharapkan menjadi masukan bagi auditor pada KAP di Provinsi Bali untuk senantiasa meningkatkan pemahaman dan kepatuhan terhadap anggaran waktu dan tugas sehingga Time Budget Pressure dan Due Professional Care mencapai kinerja yang lebih optimal demi meningkatkan kualitas audit yang dilaksanakan. Penelitian ini memiliki keterbatasan dikarenakan penelitian ini mengunakan data primer yang diperoleh melalui kuesioner, yaitu kemungkinan terjadi perbedaan presepsi antara peneliti dan responden karena responden dan peneliti tidak dapat saling mengklarifikasi pertanyaan atau pernyataan.

\section{REFERENSI}

Arens, A.A., S.B Mark, R.J. Elder, dan A.A. Jusuf .2011. Jasa Audit dan Assurance, Pendekatan Terpadu. Buku 1.Salemba Empat. Jakarta.

Alim, M.N., T. Hapsari, dan L. Purwanti. 2007. Pengaruh Kompetensi dan Independensi Terhadap Kualitas Audit dengan Etika Auditor Sebagai Variabel Moderasi. Simposium Nasional Akuntansi X Makasar. 26-28 Juli. Unhas: 1-26. 
Arisinta, O. 2013. Pengaruh Kompetensi, Independensi, Time Budget Pressure, dan Audit Fee Terhadap Kualitas Audit Pada Kantor Akuntan Publik Surabaya. Jurnal Ekonomi dan Bisnis. 3:266-278

Aldrman, C Wayne dan James W. Deitrick. 1982. "Auditor's perceptions of Time Budget Pressures and Premature Sign Offs : A Replication and Extension". Auditing: A Journal of Practice and Theory.

Al-Khaddash, Husam, Rana Al Nawas, Abdulhadi Ramadan, 2013. Factors Affecting The Quality of Auditing. The Case of Jordanian Commercial Bank. International Journal of Bussiness and Social Science. 4 (11), pp: 117.

Alderman, C.W., dan J. W Deitrick. 1982. Auditors' Perception of Time Budget Pressure and Premature Sign-Off. Auditing: A Journal of Practice and Theory (Winter).

Bawono, I. R., dan E. M . Singgih. 2010. Pengaruh independensi, pengalaman, due professional care dan akuntabilitas terhadap kualitas audit (studi pada KAP 'big four' di Indonesia). Simposium Nasional Akuntansi XIII.

Batubara, Rizal Iskandar. 2008. Analisis Pengaruh Latar Belakang Pendidikan, Kecakapan Profesional, Pendidikan Berkelanjutan, dan Independensi Pemeriksa terhadap Kualitas Hasil Pemeriksaan. Tesis. Universitas Sumatera Utara Medan.

Basuki dan Krisna Yunika Mahardani., 2006. Pengaruh Tekanan Anggaran Waktu terhadap Perilaku Disfungsional Auditor dan Kualitas Audit pada Kantor Akuntan Publik di Surabaya. Jurnal Maksi,vol. 6, no. 2, p. 203-221.

Badjuri, Acmad. 2011. Faktor-Faktor yang Berpengaruh Terhadap Kualitas Audit Independen Pada Kantor Akuntan Publik (KAP) di Jawa Tengah. Jurnal Studi Ekonomi. 3 (2): 183-197.

Baotham, Sumintorn. "Effects of Professionalism on Audit Quality and Self-Image of CPAs in Thailand", International Journal of Bussines Startegy, 2007.

Choo, Freddie, dan Ken T. Trotman. 1991. The Relationship Between Knowledge Structure and Judgment for Experienced and in Experienced Auditors. The Accounting Review (July), pp: 464-485.

Cholifa, Saydah. 2015. Pengaruh Due Professional Care, Akuntabilitas dan Time Budget Pressure Terhadap Kualitas Audit. STIESIA. Surabaya.

Coram, Paul et al., "The Moral Intensity of Reduced Audit Quality Acts. Working Paper", The University of Melbourne, Australia, 2004. 
De Angelo, L. E. 1981. Auditor Size and Audit Quality. Journal of Accounting and Economics, Vol.3, No.3, pp: 183-199

Deis, Donald L. Dan Gari A. Giroux. 1992. "Determinants of Audit Quality In The Public Sector". The Accounting Review, Vol. 67, No. 3 ( Juli). Pp. 462-479.

Elfarini, Eunike Christina. 2007. Pengaruh Kompetensi dan Independensi Auditor terhadap Kualitas Audit. Penelitian. Universitas Negeri Semarang.

Febriyanti, R. (2014). Pengaruh Independensi, Due professional Care dan Akuntabilitas Terhadap Kualitas Audit. Fakultas Ekonomi Universitas Negeri Padang.

Futri, Putu Septiani dan Juliarsa Gede. 2014. Pengaruh Independensi, Profesionalisme, Tingkat Pendidikan, Etika Profesi, Pengalaman dan Kepuasan Kerja Auditor Pada Kualitas Audit Kantor Akuntan Publik Di Bali. E-Jurnal Akuntansi.

Ghozali, Imam. 2011. Aplikasi Analisis Multivariance dengan Program SPSS. Edisi 4. Semarang: Universitas Diponegoro.

Ghozali, Imam. 2013. Aplikasi Analisis Multivariate dengan Program SPSS. Edisi Ketujuh. Semarang : Badan Penerbit Universitas Diponegoro.

Ghozali, Imam. 2014. Partial least squares konsep. Metode dan Aplikasi Menggunakan Program Warp PLS 4.0. Semarang : Badan Penerbit Universitas Diponegoro.

Gasperz, Jefry. 2014. Pengaruh Tekanan Anggaran Waktu Sebagai Variabel Moderasi terhadap Hubungan Antara Faktor Individu dan Kualitas Audit. E-jurnal Fakultas Ekonomi Universitas Pattimura, 3(1), pp:33-45.

Gundry, Leanne., dan Gregory A. Liyanarachchi. (2007). Time Budget Pressure, Auditor' Personality Type, and The Incidence of Reduced Audit Quality Practices. Pacific Accounting Review University of Otago, Vol.19 Iss 2.

Hardiningsih dan Oktaviani. 2012. Pengaruh due professional care, etika dan tenur terhadap kualitas audit. (Perspektif expectation theory). Unisbank Semarang.

Hutabarat, Goodman. (2012). Pengaruh Time Budget Pressure dan Etika Auditor terhadap Kualitas Audit. Jumlah Ilmiah Universitas Satya Negara Indonesia, Vol.6, No.1, 2012. 
Ikatan Akuntansi Indonesia. 2044. Standar Professional Akuntan Publik Jakarta: Salemba Empat.

Indah, Siti Nur Mawar. 2010. "Pengaruh Kompetensi dan Independensi Auditor Terhadap Kualitas Audit (Studi Empiris Pada Auditor KAP Di Semarang)”. Skripsi Program Sarjana Fakultas Ekonomi Universitas Diponegoro.

Jensen, M. C and Meckling, W.H. 1976. Theory of the Firm : Managerial Behavior, Agency Costs and Ownership Structure. Jurnal of Financial Economics. Oktober. 1976. V. 3. No. 4. Pp. 305-360. Available from: http://papers.ssrn.com

Jusup, Al.Haryono. 2014. Auditing: Pengauditan Berbasis ISA. Yogyakarta. Bagian Penerbitan Sekolah Tinggi Ilmu Ekonomi YKPN

Kurnia, W., Khomsiyah dan Shopie. 2014. Pengaruh Kompetensi, Independensi, Tekanan Waktu dan Etika Auditor terhadap Kualitas Audit. E-Journal Fakultas Ekonomi Universitas Tri Sakti, Volume 1(2), pp: 49-67.

Kusharyanti. 2003. Temuan penelitian mengenai kualitas audit bdan kemungkinan topik penelitian di masa datang. Jurnal Akuntansi dan Manajemen (Desember). Hal. 25-60.

Liyanarachchi, G.A., Shaun M. McNamara. 2008. Auck land University Bussines Review Volume 9 No2 : "Time budget pressure in New Zealand audits."

Muhshyi, A. 2013. Pengaruh Time Budget Pressure, Risiko Kesalahan, dan Kompleksitas Terhadap Kualitas Audit. Skripsi. Fakultas Ekonomi dan Bisnis. Universitas Islam Negeri Syarif Hidayatullah. Jakarta.

Mulyadi. 2009. Auditing. Edisi 6. Buku 1. Salemba Empat. Jakarta.

Mansur, Tubagus. 2007. Faktor-Faktor yang Mempengaruhi Kualitas Audit Ditinjau dari Persepsi Auditor atas Pelatihan dan Keahlian, Independensi dan Penggunaan Kemahiran Profesional. Tesis Program Studi Magister Sains Akuntansi Universitas Gadjah Mada (Tidak Dipublikasikan).

Prasita, A. dan P.H. Adi. 2007. Pengaruh Kompleksitas Audit dan Tekanan Anggaran Waktu Terhadap Kualitas Audit dengan Moderasi Pemahaman Terhadap Sistem Informasi. Jurnal Ekonomi dan Bisnis.

Prasetyo, Eko Budi dan I Made Karya Utama. 2015. Pengaruh Independensi, Etika Profesi, Pengalaman Kerja dan Tingkat Pendidikan Auditor pada Kualitas Audit. E-jurnal Akuntansi Universitas Udayana, 11 (1), pp: 115129. 
Pancawati Hardiningsih \& Rachmawati Meita Oktaviani. 2012. Determinan Kebijakan Hutang (Dalam Agency Theory dan Pecking order teory). ISSN : 1779-4878.

Robyn A. Monorey and Peter. 2008. Industry Versus Task Based Experience Auditor Performance. Disampaikan pada Accounting and Finance Association of Australia and new Zealand Conference, Australia.

Rhode, J. 1978. The Independent Auditors' Work Environment: A Survey. Commision on Auditor Responsibilities, Research Study No.4. New York: AICPA.

Ridwan dan Sunarto. 2007. Pengantar Statistik untuk Penelitian Sosial Ekonomi. Komunikasi dan Bisnis. Bandung : Alfabeta.

Singgih, Elisha Muliani dan Icuk Rangga Bawono. 2010. Pengaruh Independensi Pengalaman,Due Professional Care dan Akuntabilitas terhadap Kualitas Audit.SNA XIII UJSP. Purwokerto.

Saripudin, Netty Herawaty dan Rahayu. 2012. Pengaruh Independensi, Pengalaman, Due Professional Care dan Akuntabilitas Terhadap Kualitas Audit (Survei terhadap Auditor KAP di Jambi dan Palembang). Universitas Jambi: Jambi.

Sugiyono. 2014. Metode Penelitian Kuantitatif, Kualitatif dan R\&D. Bandung: Alfabeta.

Sososutikno, Christina. 2003. Hubungan Tekanan Anggaran Waktu dengan Perilaku Disfungsional serta Pengaruhnya terhadap Kualitas Audit. Simposium Nasional Akuntansi VI, Oktober: 1116-1124.

Tjun Tjun, Lauw, Elyzabet I. Marpaung dan Santy Setiawan. 2012. Pengaruh Kompetensi dan Independensi Auditor terhadap Kualitas Audit. Disertasi Fakultas Ekonomi Universitas Kristen Maranatha.

Trisnaningsih, Sri. 2007. Independensi Auditor dan Komitmen Organisasi Sebagai Mediasi Pengaruh Pemahaman Good Corporate Governance, Gaya Kepemimpinan dan Budaya Organisasi terhadap Kinerja Auditor. Simposium Nasional Akuntansi X. Makasar.

Wulandari, Soliyah. 2014. Analisis Faktor-Faktor yang Mempengaruhi Auditor dalam Memberikan Opini Audit Going Concern. Volume-No.3. Maret. 
Wibowo, Arie dan Rossieta, Hilda. 2009. "Faktor-Faktor Determinasi Kualitas Audit- Suatu Studi dengan Pendekatan Earning Surprise Benchmark”. Simposium Nasional Akuntansi XII. Palembang. 